\title{
Social Media as Predictor of Job Search Skills among Undergraduates of Obafemi Awolowo University, Ile-Ife, Osun State, Nigeria
}

\author{
Agun Tolulope Francisca \\ Department of Educational Foundations and Counselling \\ Obafemi Awolowo University, Ile-Ife, Nigeria \\ Atoyebi Adeola Olusegun \\ Department of Educational Foundations and Counselling \\ Obafemi Awolowo University, Ile-Ife, Nigeria \\ E-mail: adeola671@gmail.com
}

\begin{abstract}
The study investigated the level of job search skills among undergraduates of Obafemi Awolowo University, Ile-Ife Osun state and determined the predictive ability social media on job search skills. It examined the influence of the social media on job search skills of undergraduates of the university, Further, it investigated the influence of demographic variables (sex, age and level) and area of specialisation on job search skills of the undergraduate students. These were with a view to providing information on the factor that could improve the job search skills of O.A.U undergraduate students. The study adopted a descriptive survey research design. The population for the study comprised 26,000 undergraduates of the Obafemi Awolowo University, Ile-Ife, Osun State as at 2016/2017 academic session. The study sample comprised 496 students were selected using a multi-stage sampling procedure. Out of the thirteen faculties, four faculties were selected using simple random sampling technique. Four departments were selected from each of the selected faculties using simple random sampling technique. Purposive sampling technique was used to select graduating students (Parts 4 or 5) from each of the faculties selected. One hundred and twenty-five undergraduates were selected from each faculty, using convenience sampling technique. An instrument titled "social media of Job Search Skills" was adapted from existing standardised instruments and used to collect data. Data collected were analysed using percentage, frequency counts, mean, standard deviation, linear regression, and ordinal logistic regression. The result showed that $21.4 \%, 55.6 \%$ and $23.0 \%$ of undergraduates of Obafemi Awolowo University students demonstrated low, moderate and high levels of job search skills respectively. Also, the predictive ability of social media showed that social media $(0.323, \mathrm{p}<0.000)$ had a significant influence on students' job search skills. The study concluded that social media could improve the job search skills among undergraduates of OAU.
\end{abstract}

Keywords: Job Search Skills, Social Media.

\section{Introduction}

During the past years, the Nigerian economy has suffered downfalls and the rates of unemployment have been increasing, result being a difficulty to find a job after graduation. It has become difficult to find jobs in any specific field for graduates. Basically, a university degree or equivalent is no more a passport to get a job. Traditionally, the tertiary institutions have been aiming to prepare students for different positions in the field of work; so that after graduation, these students will start looking and applying for jobs that match their educational background.

Job search skills are those abilities that predispose individuals to ease of job placement; to search and secure a job; one has to possess job search skills. Also, some skills are attained by attending schools, industrial attachments or training programmes but others can be acquired through experiential learning on the job. Some undergraduates acquired their job search skills from different professional bodies like the Institute of Chartered Accountants of Nigeria (ICAN), Association of National Accountants of Nigeria (ANAN), Nigeria Institute of Management (NIM), Chartered Institute of Personnel Management in Nigeria (CIPM) and Business Education Examination Council (BEEC) which could determine their level of confidence in searching and getting job.

From the researcher interaction with students, it is assumed that not every graduating student is likely to possess job search skills and they may not have the same degree of confidence in their ability to find work, which may influence their job search skills. Several job search skills are fairly broad which includes good communication, word processing, and problem-solving skills. Depending on the type of work at hand, for instance, a construction worker needs a unique set of abilities different from lawyers, doctors, or teachers. Different job employers set out the skills required for a particular job, and job seekers also typically list their relevant qualifications in their application materials which may include the ability to listen well, to take and apply instructions, use of a phone, computer literacy, e-mail skills and to maintain focus for long periods of time, which are critical to 
success in almost every workplace. Most of the time, these categories of skills were assumed that employers expect employees to exhibit these categories of skills, even if they do not ever say so directly. Outdated school curricula and lack of employable skills were identified by Okafor (201I) as a causal factor of youth unemployment in Nigeria. Hence, the argument of some scholars and observers is that, as far as the formal sector is concerned, the average Nigerian graduate is not employable because there are no adequate jobs in Nigeria. And that the graduates do not possess the skills needed by the employers of labour for a formal employment. Employers thus resort to a series of job examinations, aptitude tests and interviews after interviews to sieve out an employable graduate amidst the unemployed graduated youths. Despite that Nigeria is in a situation of economic collapse; if Nigeria gets better graduates; they would be able to use the job search skills acquired from the university to search for a job and get empolyed at the end of the day.

The course contents or curricula of some tertiary education in Nigeria lack adequate entrepreneurial contents and job search skills (such as specific skills, necessary skills and sufficient skills) that would have enabled graduates to become job creators rather than job seekers. Lack of these job search skills makes it difficult for most of the undergraduates to secure a job after graduation. Also, Job advertisements and openings typically presume a basic level of proficiency when it comes to the basic skills needed to carry out the job. Undergraduates seeking job can learn many things once they have started, but they usually need to have at least a specific foundation from which to begin. Listing a relevant internship on a job application is a great way to demonstrate needed skills. For instance, undergraduates' market place. Several industries offer university students the opportunity to work as interns, usually on a part-time basis, in order to test out a certain career path. Interns are not generally paid full salaries but usually receive stipends, so they work primarily for the experience and the best place to showcase skills is on curriculum vitae. Undergraduates, who have particularly notable or unusual skills such as foreign language fluency, often list these in a special relevant skills section on their curriculum vitae. This is generally reserved for skills that will help the applicant stand out from the crowd where listing basic aptitudes is not usually necessary. In most cases, employees' job skills grow over time.

Social media is the use of internet means to get connected with recent and needed information on job opening from friends and others.. It is not certain if undergraduates of Obafemi Awolowo University (OAU) possess a similar level of job search skills.

Social media as a sociological factor influences job search among undergraduates which quickly becomes an absolute necessity to successfully apply to major corporations, and especially modern types of business such as web companies and application developers. Social media is the medium through which people, like graduates, undergraduates, and uneducated people share, hear and link up to a job advert. Some students visit the internet often and make use of the adverts on the television channels, radio stations, and newspaper as a mode of applying or searching for a vacancy in government and private firms. It is necessary to examine how they engage with the social media tools that support networks in online environments in relation to job search.

Arising from the present study, it is pertinent to investigate and provide information on the job search skills that students need, and the level of skills required which may vary depending on the type of job and the company they want to work with. Graduating students searching for a job are expected to be able to plan and organise effectively. Hence, It is important to study social media if it could predict job search skills among undergraduates of OAU so that there would be no mismatch of skills while searching for a job in order to reduce the rate of unemployment in Nigeria. Besides, it would be valuable to associate social media with job search skills measures, to see if there will be a significant influence on students' job search skills among Obafemi Awolwo University undergraduates.

\section{I.I Purpose of the Study}

The main purpose of the study is to examine the level of job search skills and social media among undergraduates of Obafemi Awolowo University, Ile-Ife.

The specific objectives of the study are to:

- Investigate the level of job search skills of undergraduates of Obafemi Awolowo University, Ile-Ife;

- Determine the predictive ability of social media on job search skills of undergraduates in the study area

- Examine the influence of the social media on job search skills of undergraduates of the university

\section{I.2 Research Questions}

The following research questions were raised to achieve the purpose of the study:

- What is the level of job search skills among undergraduates of Obafemi Awolowo University?

- What is the predictive ability of social media on job search skills of undergraduates in the study area?

\section{I.3 Research Hypotheses}

The following hypothesis was postulated

- Social media has no significant influence on job search skills of OAU undergraduates. 


\section{Methodology}

The study adopted the descriptive survey research design. It entails the process of collection of data from a representative sample of the population to possibly determine the effect of one variable on the other. The descriptive survey design was used for the study because the research is concerned with the collection of data for the purpose of describing and interpreting the social media as a predictor of job search skills among undergraduates of Obafemi Awolowo University Ile-Ife, Osun State, Nigeria. In this study, social media as a predictor represented the independent variables while job search skills represent the dependent variable. Job search skills were measured using job search skills scale to establish the level of job search skills and social media was also measured using social media questionnaire. Since all university undergraduates cannot be reached, the study had to be conducted using samples of undergraduates of Obafemi Awolowo University Ile-Ife, Osun State in which the results obtained from this was used to generalise for the entire population.

The population for the study comprised 26,382 undergraduates of Obafemi Awolowo University (OAU), Ile-Ife as at 2016/2017. The population of the male is 15,404 representing $58.4 \%$ of the population while 10,978 representing $41.6 \%$ of the population are females.

The instruments were validated with the help of experts in Tests and Measurement and Psychology of Education at Obafemi Awolowo University, Ile-Ife. Kaiser-Olkin Measure of Sampling Adequacy (KMO) and Bartlett's Test of Sphericity (BTS) were carried out to ascertain the usability of factorial validation for the validation of the items in each section of the questionnaire and each item yielded uniform data. The Kaiser-Meyer-Olkin Measure of Sampling Adequacy (KMO) value for job search skills and social media media were 0.642 and $0.62 \mathrm{I}$ respectively which is greater than critical value at 0.05 level of significance and so is acceptable. The Cronbach's Alpha approach was adopted in determining the reliability of the scale and it yielded a coefficient of 0.852 and 0.895 .

\section{Results}

Research Question I: What is the level of job search skills among undergraduate of Obafemi Awolowo University?

To answer this question, items in Section B with a four-point Likert scale "Strongly Agree with Strongly Disagree were scored I through 4 respectively for each statement. On the scale, a minimum and maximum scores obtained were 18 and 36 respectively with a mean and standard deviation ( $=29.01, \mathrm{SD}=3.37$ ). In the study, scores that ranged between the minimum obtained score and the mean minus one standard deviation (18-26) indicated low job search skills, while scores that were higher than the mean minus one standard deviation but less than the mean plus one standard deviation (27-3I) indicated that the students were having average job search skills and scores that ranged from the mean plus one standard deviation and the maximum obtained score (32-36) indicated that the students were having high job searching skills. The result is as presented in Table I.

Table I. Descriptive Statistics Showing the level of job search skills of participant

\begin{tabular}{llll}
\hline $\begin{array}{l}\text { Levels } \\
\text { skills }\end{array}$ & of Job Search & N & $\%$ \\
\hline \multirow{3}{*}{} & Low & I06 & 21.4 \\
\cline { 2 - 4 } & Average & 276 & 55.6 \\
\cline { 2 - 4 } & High & I I4 & 23.0 \\
\cline { 2 - 4 } & Total & 496 & I00.0 \\
\hline
\end{tabular}

From Table I, it was observed that only 21.4\% of sampled Obafemi Awolowo University students have low job search skill, while $55.6 \%$ of the sampled students have average job search skills when compared with others and $23.0 \%$ have high job search skills.

Research Question 2: What is the predictive ability of social media on job search skills?

To answer this question, regression analysis was carried out on the available data using the data for job search skills as dependent variable and social media as the independent variable. The result is as presented in Table 2

Table 2. The predictive ability of social media on job search skills

\begin{tabular}{|c|c|c|c|c|}
\hline $\begin{array}{l}R=0.487 \\
R^{2}=0.237\end{array}$ & Unstandardised Coefficients & $\begin{array}{l}\text { Standardised } \\
\text { Coefficients }\end{array}$ & $\mathrm{t}$ & Sig. \\
\hline $\begin{array}{l}\text { Adj } R^{2}=0.230 \\
F=30.395^{*}\end{array}$ & Std. Error & Beta & & \\
\hline
\end{tabular}




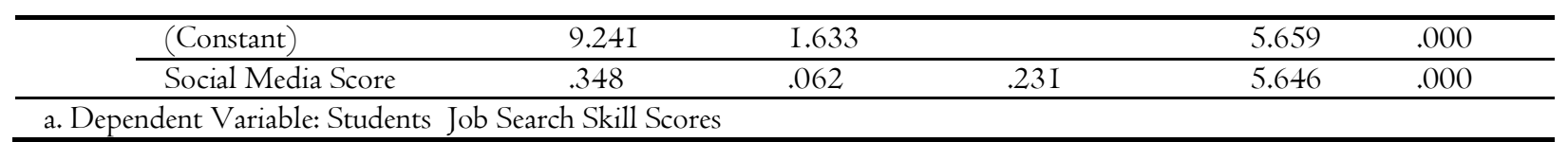

The Model Summary as presented in Table 2 showed the multiple $r$ and coefficient of determination $\left(\mathrm{r}^{2}\right)$ for the regression model. The $\mathrm{r}^{2}=0.237$ indicated that $23.7 \%$ of the variance in students' job search skill score can be explained by the regression model. The significant $\mathrm{F}$-value $(\mathrm{F}=30.395, \mathrm{P}<0.05)$ as observed in the Table indicated that the model predicted the outcome accurately. Table 2 also showed the constant or intercept term and the regression coefficients $(\beta)$ for independent variable. The constant value (9.24I) represents the intercept, which is the predicted job search skill not accounted for by the independent variable. The unstandardised beta values $(\beta=0.348)$ social media showed that there is a significant predicted increase $34.8 \%$ in students' job search skill respectively. However, for every unit increase in peer influence, there is a nonsignificant increase of $1.8 \%$ in students' job search skill. The regression equation therefore is "Students job search skills $=9.24 \mathrm{I}$ $+0.237,0.348$ (social media).

Hypothesis I: Social media has no significant influence on job search skills of undergraduates

To test this hypothesis, ordinal logistic regression was carried out with job search skills having three categories (low, average and high) as the dependent variable and social media score as the independent variable. The result is presented in Table.

Table 3. Parameter estimates showing the influence of social media on job search skills of undergraduates

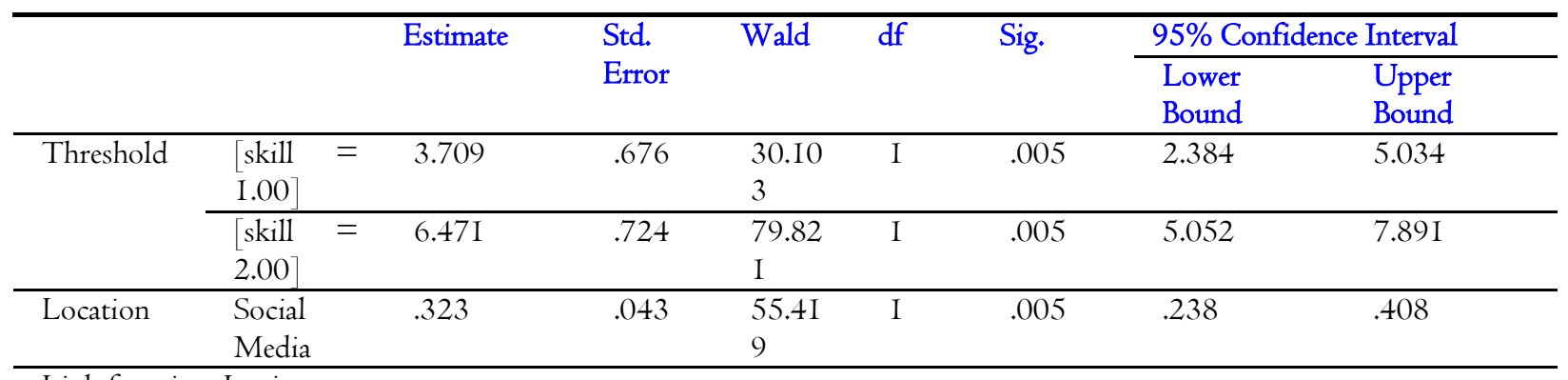

Link function: Logit.

In Table above, the Estimate column showed the coefficient for the independent variable to be 0.323 which means that there is a positive influence of social media on job search skills. That is a unit increase in social media use brings about a significant increase in the students' job search skill at $p=0.000$. Thus, it could be inferred that social media has a significant influence on job search skill.

\section{Discussion of Findings}

The result of the present study shows that the majority of OAU undergraduates possessed a moderate level of job search skills which may help them to be able to search and secure a job after graduation from the university. This finding is similar to Jaquiline (2013) which asserted that undergradutes intentions to join their careers were highly determined by their level of occupational knowledge and social influence. Greenberger (2002) stated that the environment plays a significant role in the career position the student attains in many ways. The environment that is spoken about here is a factor that is used to nurture the job search skills. Attieku (2005) asserted the level of the individual's educational attainment also counts while searching for a job. It is true that one who enrolls and studies in a medical school will become a medical doctor and one who attends the school of journalism is likely to be a journalist. From this study, it could be seen that students possessed different levels of job search skills

From this study, it could be seen that students possessed different levels of job search skills and this is not in line with the assertion of (Vansteenkiste, 2005) that, there might be other reasons for the failure to find a positive relation between job searching and expectancy. Vansteenkiste (2005) observed that, unemployed people who are confident about finding a job might (temporarily) give priority to alternative activities in their lives, before looking for a new job. Secondly, people's high expectations might be due to the fact that there are many jobs available in the job market; and therefore one does not have to engage in a frequent search for them. Third, unemployed people with high expectations of finding a job might be so confident about finding a job that they do not see any reason to start their job search. Confident people might believe that they have the necessary skills and competencies that will get them a job when they begin their search, whereas people with low confidence of 
finding a job might believe that they lack some of the required skills and competencies and therefore search harder. The present study in line with previous research by Vinokur \& Schul, (1997) observed that the more confident undergraduates and unemployed people search for job in the near future, the less they experienced their lives as meaningless and empty, the less they felt abandoned and socially isolated, and the higher were their reported mental health scores.

Also, the study showed that students in their final academic year had greater career capabilities (Jameson \& Holden, 2000) suggest that if students are not concerned with their employment in the last year of study, their passiveness could result in stressful periods when they graduate. During this time individual could be vulnerable and they may feel disoriented and unduly affected by any career plans proposed by potential employers, while they display passiveness in their career attitudes, resulting in a job below their qualification.

It was also discovered from the study that social media could predict job search skills of undergraduates of Obafemi Awolowo University, Ile-Ife.

According to hypothesis four, there was a positive influence of social media on job search skills. And this is in line with McDonald \& Crew (2006) who also reported a positive association between the number of Internet job search strategies (i.e., reading online job advertisements or searching online job listings, submitting an application to an employer online, researching information about potential employers, and posting a resume on a job listing site or a service online) and five out of six of the job quality indicators defined in the study. The indicators that were positively related to job search intensity were a log of hourly wages, pension, healthcare, and health care for children and training (no significant association was found with full-time employment). In relation to offline search, the analysis suggested no association between its intensity in terms of a number of strategies employed and job quality.

The findings of this study also corresponded with the conclusion of Kuhn \& Skuterud (2000) that Internet use (social media) can be associated with the increased use of certain job search methods. While Kuhn and Skuterud were able to confirm this relationship only in relation to sending out CVs, filling in job applications and 'other search methods', Stevenson's study (2008) also indicated an increase in other methods (such as looking for advertisements and contacting private employment agencies) due to increased Internet penetration.

It was noted from this study that social media also influences job search skills among undergraduates. From the use of social media, students may be listening to radio adverts, browsing various search engines, applying for job online and watching television adverts on how to search and secure job after graduation from the university and this could be possible through the acquisition of job search skills during undergraduate days.

Finally, it is therefore noteworthy that self-esteem had the strongest influence on students' job search skills. From the study, it was discovered that the student who make use of social media and who is able to control himself/herself tends to possess job search skills before leaving the university and will be able to search and secure a job after graduation.

\section{Conclusion}

The present study established that majority of undergraduates possessed a moderate level of job search skills. The predictive ability of social media on students' job search skills is significant. It was also concluded that social media could predict job search skills among undergraduates of OAU.. Even though undergraduates have good knowledge of job search skills but there is still need for improvement with the help of social media usage.

\section{Recommendations}

Based on the conclusion of this study, these recommendations are proposed to further enhance job search skills which will help students to get a job after graduation from the university. There recommendations are given subsequently.

There should be efforts by school counselling unit of the tertiary institutions to improve and develop the level of job search skills of undergraduates. All teachers should be equipped with counselling skills by the Nigeria Education service to enable them involve in career guidance activities of the school. The view that career education and guidance are often considered being the sole responsibility of the specialist career guidance staff, rather than the joint responsibility of all members of the teaching staff has to be discarded. It is also necessary to motivate graduating students in the process of job searching so as to reduce the continuous increase in the current rate of unemployment.

Counsellors and lecturers should create sensitization on how to help undergraduates to develop curriculum vitae, cover letters, learn about job openings, how to prepare for job interview, registering with some consultancy organisations who provide job alerts and how to use social media tools while searching for a job. Undergraduates should make realistic commitments to their academic pursuits in other to know how to avoid mismatch of skills needed in a specific job so that they will not become employed and underemployed after university graduation.

Undergraduates should have good knowledge of how social media could influence their job search outcomes. Government as a matter of urgency has to enter into partnership with NGO'S and other donor agencies to raise adequate fund to create job opportunities in the country to solve problem of inadequate jobs reported by the guidance and counselling coordinators because there is good knowledge of job search skills by undergraduates to secure job. Government should also create enabling 
environment to encourage the private sector to create jobs to have lasting solution to unemployment problems. School counsellors should organise periodic career seminars for undergraduates on how to develop the use of social media and these could enhance job search skills.

\section{References}

Attieku, B., Dorkey, T., Marfo-Yiadom, E., \& Tekyi, K. (2006). Business management-GABET series (Ist ed.), Cape Coast: Nyakow Printing Press.

Greenberger, M. (2002). Nation's high schools still operate "separate and unequal" Thousand Oaks, CA: Sage.

Jaquiline, A. (2013). Social Influence and Occupational Knowledge as Predictors of Career Choice Intentions among Undergraduate Students in Tanzania. International Journal of Learning and Development, 3(3).

Jameson, S., \& Holden, R. (2000). "Graduateness" - Who Cares? Graduate Identity in Small Hospitality firms. Journal of Education and Training, 42(4), 264-27I.

McDonald, S., \& Crew, R. E. (2006). Welfare to Web to Work: Internet Job Searching Among Former Welfare Clients in Florida. Journal of Sociology \& Social Welfare. 33(I), 239-253.

Okafor, E. E. (20I I). Youth Unemployment and Implications for Stability of Democracy In Nigeria. JSDA, Vol.I3, No. I. Retrieved from http://www.jsdafrica.com/Jsda/VI3NoI_Spring20II.

Stevenson, B. (2008). The Internet and Job Search, National Bureau of Economic Research Inc, NBER Working Papers: I3886.

Vansteenkiste, M., Lens, W., De Witte, H., \& Feather, N. (2005). Understanding unemployed people's job-search behaviour, unemployment experience and wellbeing: A comparison of expectancy-value theory and self-determination theory. British Journal of Social Psychology, 44, I-20.

Vinokur, A., \& Schull, R. D. (1997). Attitudes and social support: Determinants of job-seeking behaviour and well-being among the unemployed. Journal of Applied Social Psychology, I7, I007-I024.

\section{Copyrights}

Copyright for this article is retained by the author(s), with first publication rights granted to the journal.

This is an open-access article distributed under the terms and conditions of the Creative Commons Attribution license

(http://creativecommons.org/licenses/by/4.0/) 